\title{
Effects of Apricot and Apricot Kernels on Human Health and Nutrition: A Review of Recent Human Research
}

\author{
Hawar Jawdat Jaafar \\ Department Of Medical Laboratory Techniques (MLT), Erbil Health Technical College, Erbil \\ Polytechnic University, Iraq
}

\begin{abstract}
Plants are one of the most important sources of medicine for humans to face diseases and disorders. Despite some advances in the field of allopathic system of medicine, adverse reactions have not been prevented from being an integral part of modern medicine. Plants are one of the important sources of drug discovery in both modern and traditional medicine systems worldwide. Recent developments in food and nutrition, consumer preferences shifted to foods rich in nutraceuticals. Furthermore $70 \%$ of marketed drugs are either natural or semisynthetic materials which derived from plants. Most literature on complementary alternative medicine worldwide either reports the nature of phytocomponents in medicinal plants or shows a mechanistic basis for their pharmacological activities. The medicinal and therapeutic effect of apricot has not been studied so far. In this review, an attempt has been made highlight the importance of apricot and its kernel in human health and nutrition by summarizing the literature reports published to date. Apricot exhibited diversified effects on degenerative diseases such as cancer, cardiovascular and hemostasis, at the same time has many pharmacological effects such as antiparasitic, anti-aging, anti-atherosclerosis, renoprotective, hepatoprotective and antioxidant have been reported.
\end{abstract}

Keywords: Apricot, pharmacological importance, apricot nutrition, phytochemical compositions, apricot kernels 


\section{INTRODUCTION}

Apricot (Prunus armeniaca L.) belongs to the Rosaceae family. In Angiosperms, Rosaceae is one of the largest families with around 3,400 species which includes almonds, apples, peaches, plums, strawberries and cherries, distributed throughout the northern temperate regions of the world. Apricot has been named by Romans most probably from the mixed accent of two words "praecocia" from Latin meaning "early matured", since apricots were ripen during early summer as compared to ancient Asian peaches or "albarquq" from Arabic, meaning short ripening period (Anonymus, 2008). It is a temperate fruit and grows in climates with welldifferentiated seasons. It requires a fairly cold winter and moderately high temperatures in the spring and early summer (Ahmadi et al., 2008; Guclu et al., 2006). Botanically, apricots are drupe fruits such as peaches, plums, cherries and mangoes in which the outer fleshy part (exocarp and mesocarp) surrounds a hard stone (endocarp) with seeds inside. Fruit color ranges from orange to orange red, and some cultivars are creamy white to greenish white (Ruiz et al., 2005; Riu-Aumatell et al., 2005). The apricot originates from China and dates back to $2000 \mathrm{BC}$ (Crisosto et al., 1999; Faust et al., 1996). Gradually they made their way through the Persian Empire to the Mediterranean, where they were best adapted. This fruit has also been grown on the mountainous slopes of Asia and Europe for thousands of years. Spanish explorers introduced this fruit to the new world and it was planted in the gardens of Spanish missions in California (Faust et al., 1996). Currently, the main apricot planting zones include a strip stretching from Turkey to Iran, the Himalayas, the Hindu Kush, China, and Japan. However, the largest production of apricots in the world is provided from Mediterranean countries (Leccese et al., 2007). According to FAO statistics (2019), Turkey has a share of $19.7 \%$ in world apricot production with a production of 985000 tons in 2017. According to 1980 data, Turkey's apricot production increased 5.1 times (Table 1) (FAO STAT, 2019). Current trends in nutritional sciences have led consumers to consume healthy foods, especially fruits and vegetables, in order to meet their nutritional needs and maintain a healthy life. Fruits are a good combination of nutrition and health promoting ingredients. In addition to its basic nutritional content, it carries a significant amount of antioxidant and phenolic compounds with important pharmacological roles (Martínez-Navarrete, 2012). The shelf life of apricots is often extended by different preservation methods, such as canning, freezing, drying or packaging in a controlled atmosphere. Drying reduces the moisture content of apricots to a safe level and allows long-term storage (Doymaz, 2004; Huang et al., 2013; Igual et al., 2012). Therefore, this article aims to explore and summarize the current research information regarding the nutritional and health benefits of apricot fruit, however, number of researchers have reported the benefits of consuming different fruits, including apricots and kernel. Additionally, a number of studies have detailed the pharmacological and biological effects of apricot. A summary of 
information compiled from published studies focusing only on apricot and its kernel are presented in this review.

\begin{tabular}{|c|c|c|c|c|c|c|c|c|}
\hline Country & & 1980 & 1990 & 2000 & 2010 & 2017 & $\begin{array}{c}\text { Share } \\
(\%)\end{array}$ & \begin{tabular}{l}
\multicolumn{1}{c}{ Index } \\
$(1980=10$ \\
$0)$
\end{tabular} \\
\hline \multirow{3}{*}{ Turkey } & $\begin{array}{l}\text { Harvested area } \\
\text { (ha) }\end{array}$ & 44075 & 49595 & 89800 & 108053 & 125049 & 11.9 & 137 \\
\hline & Yield (kg/ha) & 3630 & 6049 & 5902 & 4165 & 7877 & - & 371 \\
\hline & $\begin{array}{c}\text { Production } \\
\text { (ton) }\end{array}$ & 160000 & 300000 & 530000 & 450000 & 985000 & 19.7 & 507 \\
\hline \multirow{3}{*}{ Uzbekistan } & $\begin{array}{l}\text { Harvested area } \\
\text { (ha) }\end{array}$ & - & 12400 & 17000 & 35500 & 41711 & 7.78 & 336 \\
\hline & Yield (kg/ha) & - & 4145 & 4000 & 9155 & 12768 & - & 308 \\
\hline & $\begin{array}{l}\text { Production } \\
\text { (ton) }\end{array}$ & - & 51400 & 68000 & 325000 & 532565 & 12.51 & 1036 \\
\hline \multirow{3}{*}{ İtaly } & $\begin{array}{l}\text { Harvested area } \\
\text { (ha) }\end{array}$ & 13000 & 14042 & 15340 & 19543 & 18993 & 3.54 & 146 \\
\hline & Yield (kg/ha) & 7392 & 13154 & 13127 & 12940 & 14032 & - & 190 \\
\hline & $\begin{array}{c}\text { Production } \\
\text { (ton) }\end{array}$ & 96100 & 184710 & 201372 & 252892 & 266372 & 6.26 & 277 \\
\hline \multirow{3}{*}{ Algeria } & $\begin{array}{l}\text { Harvested area } \\
\text { (ha) }\end{array}$ & 7700 & 14010 & 13390 & 49495 & 44307 & 8.27 & 535 \\
\hline & Yield (kg/ha) & 3024 & 2497 & 4209 & 4010 & 5798 & - & 192 \\
\hline & $\begin{array}{c}\text { Production } \\
\text { (ton) }\end{array}$ & 23285 & 34979 & 56354 & 198467 & 256890 & 6.03 & 1103 \\
\hline \multirow{3}{*}{ İran } & $\begin{array}{l}\text { Harvested area } \\
\text { (ha) }\end{array}$ & 14000 & 11877 & 28692 & 81290 & 11545 & 2.15 & 82 \\
\hline & Yield (kg/ha) & 3929 & 7197 & 8703 & 4774 & 20760 & - & 528 \\
\hline & $\begin{array}{c}\text { Production } \\
\text { (ton) }\end{array}$ & 55000 & 85474 & 249700 & 388049 & 239712 & 5.63 & 436 \\
\hline \multirow{3}{*}{ Pakistan } & $\begin{array}{l}\text { Harvested area } \\
\text { (ha) }\end{array}$ & 3218 & 6400 & 12909 & 29648 & 30877 & 5.76 & 960 \\
\hline & Yield (kg/ha) & 11115 & 12656 & 9752 & 6414 & 5796 & - & 52 \\
\hline & $\begin{array}{l}\text { Production } \\
\text { (ton) }\end{array}$ & 35768 & 81000 & 125889 & 190174 & 178957 & 4.20 & 500 \\
\hline \multirow{3}{*}{ Spain } & $\begin{array}{l}\text { Harvested area } \\
\text { (ha) }\end{array}$ & 19300 & 22800 & 23487 & 18333 & 21002 & 3.92 & 109 \\
\hline & Yield (kg/ha) & 5896 & 5246 & 6067 & 4294 & 7755 & - & 132 \\
\hline & $\begin{array}{l}\text { Production } \\
\text { (ton) }\end{array}$ & 113800 & 119600 & 142498 & 78715 & 162872 & 3.83 & 143 \\
\hline \multirow[t]{3}{*}{ France } & $\begin{array}{l}\text { Harvested area } \\
\text { (ha) }\end{array}$ & 13000 & 13759 & 14992 & 13797 & 12768 & 2.38 & 98 \\
\hline & Yield (kg/ha) & 6077 & 8026 & 8724 & 10380 & 11631 & - & 191 \\
\hline & $\begin{array}{l}\text { Production } \\
\text { (ton) }\end{array}$ & 79000 & 110432 & 130787 & 143212 & 148500 & 3.49 & 188 \\
\hline \multirow{3}{*}{ Afghanistan } & $\begin{array}{l}\text { Harvested } \\
\text { area(ha) }\end{array}$ & 6820 & 5115 & 5754 & 8320 & 23890 & 4.46 & 350 \\
\hline & Yield (kg/ha) & 6965 & 7044 & 7445 & 8000 & 5518 & - & 79 \\
\hline & $\begin{array}{l}\text { Production } \\
\text { (ton) }\end{array}$ & 47500 & 36030 & 42840 & 66560 & 131816 & 3.10 & 278 \\
\hline
\end{tabular}




\begin{tabular}{|c|c|c|c|c|c|c|c|c|}
\hline \multirow{3}{*}{ Morocco } & $\begin{array}{l}\text { Harvested area } \\
\text { (ha) }\end{array}$ & - & 13500 & 13921 & 12244 & 11419 & 2.13 & 85 \\
\hline & Yield (kg/ha) & - & 5459 & 8591 & 11020 & 9856 & - & 181 \\
\hline & $\begin{array}{c}\text { Production } \\
\text { (ton) }\end{array}$ & 63000 & 73700 & 119600 & 134933 & 112538 & 2.64 & 179 \\
\hline \multirow{3}{*}{ Other coutries } & $\begin{array}{l}\text { Harvested area } \\
\text { (ha) }\end{array}$ & 172944 & 153033 & 200250 & 188440 & 194519 & 36.29 & 112 \\
\hline & Yield (kg/ha) & 6136 & 7265 & 5972 & 5719 & 6385 & - & 104 \\
\hline & $\begin{array}{c}\text { Production } \\
\text { (ton) }\end{array}$ & 1061103 & $\begin{array}{c}111178 \\
5\end{array}$ & 1195970 & 1077639 & 1242019 & 29.17 & 117 \\
\hline \multirow{3}{*}{ World } & $\begin{array}{l}\text { Harvested area } \\
\text { (ha) }\end{array}$ & 294057 & 316531 & 435535 & 564663 & 536072 & 100.0 & 182 \\
\hline & Yield (kg/ha) & 5899 & 6916 & 6574 & 5854 & 7942 & - & 135 \\
\hline & $\begin{array}{l}\text { Production } \\
\text { (ton) }\end{array}$ & 1734556 & $\begin{array}{c}218911 \\
0 \\
\end{array}$ & 2863010 & 3305641 & 4257241 & $\begin{array}{c}100.0 \\
0\end{array}$ & 245 \\
\hline
\end{tabular}

Table 1: World Apricot Production (FAO STAT, 2019)

\section{BOTANY AND CULTIVATION}

Apricot is a small tree 7-10 $\mathrm{m}$ tall with a trunk up to $40 \mathrm{~cm}$ in diameter and a dense spreading canopy. The leaves are ovate, $5-9 \mathrm{~cm}$ long and $4-8 \mathrm{~cm}$ wide, with a rounded base, pointed tip and finely serrated margin. The flowers are $2-4.5 \mathrm{~cm}$ in diameter, with five white to pinkish petals they are produced singly or in pairs before leaves in early spring. The fruit is similar to a small peach, $1.5-2.5 \mathrm{~cm}$ in diameter, yellow to orange, usually painted red on the side most exposed to the sun; its surface may be smooth or velvety with very short hairs. The flesh is usually firm and not very juicy.

The taste can range from sweet to sour. The single seed is enclosed in a hard, stony shell called a "stone", with a grainy, smooth texture, except for three ridges running down one side. A dry climate is good for fruit ripening. A limiting factor in growing apricots is spring frosts, as these plants tend to bloom in early spring (early March in Western Europe), meaning spring frost can kill the flowers. Also, trees are sensitive to temperature changes during the winter season. Apricot varieties are mostly grafted onto plum or peach rootstocks.

\section{NUTRITIONAL IMPORTANCE}

Among the pitted fruits, apricot is a carbohydrate-rich product and a good source of fiber, minerals and vitamins (Table 2,3). The carbohydrate concentration in fresh apricots varies between $11-13 \%$ and provides $50 \mathrm{kcal}$ of energy per 100g on a fresh weight basis (Lichou et al., 2003; USDA 2005; Haciseferogullari et al., 2007; Leccese et al., 2007). It is also rich in bioactive phytochemicals such as polyphenols and carotenoids, which have specific roles in the 
biological system and are effective in preventing oxidative stress (Leccese et al., 2011). These compounds also impart colors (red, blue and purple) to plant tissues and thus greatly contribute to the visual quality of fruits (Mazza and Miniati, 1993). Apricots also carry moderate amounts of dietary fiber ranging from 1.5-2.4g/100g on a fresh weight basis (Ali et al., 2011; Hacıseferoğulları et al., 2007). Fiber provides the necessary roughage and volume to the food consumed, stimulates normal gastric motility and prevents constipation, as animal model studies of apricot fiber have significantly improved fecal output (Akin et al., 2007; Tamura et al., 2011). Soluble fiber lowers blood cholesterol, maintains blood sugar levels and helps reduce body weight (Lairon, 1990). In addition, on the basis of its health benefits, fiber is accepted as a functional component and creates a great interest among functional food concepts (Pszczola, 1998).

Apricot contains various amounts of essential minerals (Table 3). The main elements are potassium, phosphorus, calcium, magnesium, iron and selenium (Munzuroğlu et al., 2003; Ali et al., 2011), sodium, manganese, zinc and copper are also found in small amounts (Lichou et al., 2003; USDA, 2005). Likewise, the vitamins found in apricots are provitamin A, vitamin C, $\mathrm{K}$, E, thiamine (B1), riboflavin (B2), niacin (B3), pyridoxine (B6), folic acid (B9) and pantothenic acid (Table 3) (Chauhan et al., 2001; Hacıseferoğulları et al., 2007). In general, apricot is especially rich in vitamins A and C (Lee and Kader, 2000). Apricot contains organic acids, namely malic acid $(500-900 \mathrm{mg} / 100 \mathrm{~g})$ and citric $(30-50 \mathrm{mg} / 100 \mathrm{~g})$ as the main acids (Table 3) (Gurrieri et al., 2001), presence of tartaric, succinic, oxalic, galacturonic, quinic, malonic, acetic and fumaric acid have also been reported (Hasib et al., 2002). From a nutritional point of view, organic acids maintain the acid-base balance in the gut and increase the bioavailability of iron (Monsen, 1982). These acids, which are natural components of many fruits and vegetables, slow down bacterial spoilage, give fruits, taste, flavor and shelf stability, and play an important role in maintaining quality and determining nutritional value (Bassi et al., 1996). Similarly, apricot kernels contain significant levels of dietary protein and significant amounts of fat and fiber (Monsen, 1982). The oil content of the seed, which is rich in unsaturated fatty acids, varies between 40-52\% (Alpaslan and Hayta, 2006; Orhan et al., 2008). 
Table 2: Approximate Composition of Apricot Fruit

\begin{tabular}{|lc|} 
Ingredients & Concentration $(\mathbf{g} / \mathbf{1 0 0} \mathbf{g} \mathbf{~ F W})$ \\
\hline Water & 83.00 \\
\hline Protein & 1.40 \\
\hline Crude fiber & $1.50-2.40$ \\
\hline Carbohydrates & $11.00-13.00$ \\
\hline Fat & 0.40 \\
\hline Ash & 0.74 \\
\hline
\end{tabular}

FW= Data presented on fresh weight basis (Chauhan et al., 2001; Akin et al., 2007; Gurrieri et al., 2001; Haciseferogullari et al., 2007)

Table 3: Vitamins, Minerals, and Organic acid Composition of Apricot

\begin{tabular}{|c|c|c|c|}
\hline Minerals & $\begin{array}{l}\text { Concentration } \\
\text { (mg/100gFW }\end{array}$ & Vitamins & $\begin{array}{l}\text { Concentration } \\
(\mathrm{mg} / 100 \mathrm{~g} \text { FW) }\end{array}$ \\
\hline Calcium (Ca) & 14.00 & Retinol (Vitamin A) & 1.56 \\
\hline Potassium (K) & 296.00 & Thiamin $\left(\mathrm{B}_{1}\right)$ & 0.02 \\
\hline Chloride (Cl) & 3.00 & Riboflavin $\left(\mathrm{B}_{2}\right)$ & 0.02 \\
\hline Copper (Cu) & 0.09 & $\operatorname{Niacin}\left(\mathrm{B}_{3}\right)$ & 0.86 \\
\hline Iron $(\mathbf{F e})$ & 0.54 & $\begin{array}{l}\text { Pantothenic acid } \\
\left(\mathrm{B}_{5}\right)\end{array}$ & 0.23 \\
\hline Magnesium (Mg & 8.00 & Pyridoxine $\left(\mathrm{B}_{6}\right)$ & 0.06 \\
\hline Manganese (Mn) & 0.06 & Folic acid $\left(\mathrm{B}_{9}\right)$ & 8.60 \\
\hline Phosphorus (P) & 19.00 & Ascorbic acid (C) & $5.00-10.00$ \\
\hline Selenium (Si) & 0.40 & Tocopherol (E) & 0.88 \\
\hline Sodium (Na) & 1.00 & Phylloquinone (K) & 3.28 \\
\hline Zinc (Zn) & 0.26 & $\begin{array}{l}\text { Organic acids } \\
\begin{array}{r}-\quad \text { Citric acid } \\
-\quad \text { Malic acid }\end{array}\end{array}$ & $\begin{array}{r}38.11 \\
952.00\end{array}$ \\
\hline
\end{tabular}

FW= Data presented on fresh weight basis (Ali et al., 2011; Chauhan et al., 2001;Haciseferogullari et al., 2007; Munzoruglu et al., 2003; Gurrieri et al., 2001). 


\section{CHEMICAL COMPOSITION}

The plant is a rich source of carbohydrates (both mono and polysaccharides) (Bassi et al., 1996), polyphenols (Socher et al., 2010; Turans et al., 2007), carotenoids (ß carotene) (Ruiz et al., 2005), vitamins $C$ and $K$, thiamine, niacin, iron, organic acids, phenols and volatile compounds, benzaldehyde, esters, norisoprenoids and terpenoids (Prasad et al., 1998; Mandal et al., 2007). It has been reported that the seeds contain the cyanogenic glycoside amygdalin (vitamin B17) (Figure 3) because when ingested, it is hydrolyzed by the enzyme $\beta$-glucuronidase to glucose, benzaldehyde and hydrocyanic acid in the alkaline environment of the small intestine and is rapidly absorbed by emulsification and circulates throughout the body and thus may be responsible for its toxic effects (Sahin, 2011). Amygdalin is used in traditional chinese medicine to relieve "blood stagnation" and to treat abscesses (Chen et al., 2004). Amygdalin is also used as an anti-cancer agent since the 1800s. Used alone or as part of a program. This may include following a particular diet, high-dose vitamin supplements, and pancreatic enzymes (Milazzo et al., 2015). This is more common in children as children have lower body mass and therefore have higher stomach acidity than adults. Ripe fruit pulp as total solids (12.4\% $16.7 \%)$, insoluble solids $(2.1 \%-3.1 \%)$, acid as malic acid (0.7-2.2\%), total as invert sugar It contains sugar (5,3-8,6\%), glucose (3,2-4,8\%). \%), fructose (1.4-4.25\%), sucrose (1.4-5.4\%), and tannins (0.06-0.10\%) (Erdogan et al., 2010).

\section{PHYTOCHEMICALS IN APRICOT}

Apricot fruit contains varying levels of phytochemicals such as polyphenols (phenolic acids and flavonoids) and carotenoids, which contribute significantly to taste, color and nutritional value (Table 4) (Dragovic-Uzelac et al., 2007). The available information on key phytochemical ingredients is summarized below:

\section{1- Phenolic Compounds}

Phenolic compounds are important plant chemicals and probably play important roles in living systems. There is great interest in polyphenols and carotenoids because of their antioxidant properties and their ability to alleviate possible chronic diseases (Gardner et al., 2000; RiceEvans et al., 1997; Vinson et al., 1998). Apricot contains phenolic compounds (phenolic acids and flavonoids), and the total phenolic composition has been reported in the range of 50.00$563.00 \mathrm{mg} \mathrm{GAE} / 100 \mathrm{~g}$ on fresh weight basis (Table 4) (Ali et al., 2011; Sochor et al., 2010; Kalyoncu et al., 2009; Akbulut and Artik, 2002). Phenolic acids such as chlorogenic, neochlorogenic, isochlorogenic, caffeic, $\beta$-coumaric, $p$-coumaric, and ferulic acid derivatives 
are most commonly found in apricots (Figure 2) (Radi et al., 1997; Sass-Kiss et al., 2005). The total flavonoid content determined in apricots has been reported in the range of 1.00$12.00 \mathrm{mg} / 100 \mathrm{~g}$ on a fresh weight basis (Arts et al., 2002; Miguel et al., 2008). The main flavonoids are flavanols, anthocyanins and flavonols, respectively. Akbulut and Artik in 2002 reported catechins as the most common phenolic compound in Turkish apricots. The flavonoids in apricots are mostly found as quercetin, kaempferol, and rutin glycosides and rutinosides (Figure 1) (Garcia-Viguera et al., 1994). Flavonoids include purple, blue, red anthocyanins and yellow anthoxanthins, which contribute greatly to the visual quality of fruits (Mazza and Miniati, 1993). Several other flavonoids such as coumarins, aesculetin and scopoletin have also been reported in apricot fruits (Fermandez de Simori et al., 1992).

\section{2- Carotenoids}

Carotenoids are bioactive compounds and the most common group of pigments in nature and are found in all photosynthetic organisms. They are giving the yellow to red color of fruits and flowers (Rao and Rao, 2007). Carotenoids act as antioxidants by scavenging reactive oxygen species that cause oxidative damage in living cells. They are probably vital in preventing many human degenerative disorders and maintaining health (Bramley, 2003). Apricot is among the fruits rich in carotenoids and its content varies between $2.00-20.77 \mathrm{mg} / 100 \mathrm{~g} \beta$-carotene (Table 4) (Ali et al., 2011; De Rigal et al., 2000; Ruiz et al., 2008). The main dietary carotenoids are $\beta$-carotene, $\gamma$-carotene and lycopene, among which $\beta$-carotene represents more than $50 \%$ of total carotenoids. Apricots can be important dietary sources of vitamin A, as $250 \mathrm{~g}$ of fresh or $30 \mathrm{~g}$ of dried apricots provide enough carotenoids to meet the body's requirements for vitamin A (Marty et al., 2005; Muller, 1996; Fraser and Bramley, 2004).

Table 4: Phytochemical Compositions of Apricot

\begin{tabular}{|c|c|c|c|}
\hline Compounds & $\begin{array}{l}\text { Concentration } \\
(\mathrm{mg} / 100 \mathrm{~g} \mathrm{FW})\end{array}$ & Compounds & $\begin{array}{l}\text { Concentration } \\
(\mathrm{mg} / 100 \mathrm{~g} \mathrm{FW})\end{array}$ \\
\hline Total phenolics (GAE) & $50.00-563.00$ & Flavonoids: & \\
\hline $\begin{array}{l}\text { Total carotenoids ( } \beta \text {-carot. } \\
\text { E.) }\end{array}$ & $2.00-20.77$ & (+)-Catechin & 3.82 \\
\hline & & (-)-Epicatechin & 4.19 \\
\hline Phenolic acids: & & Quercetin 3-rutinoside & 2.15 \\
\hline Chlorogenic acid & 2.80 & $\begin{array}{l}\text { Kaempferol 3- } \\
\text { rutinoside }\end{array}$ & $0.00-1.12$ \\
\hline Caffeic acid & 0.81 & Procyanidins & $32.00-333.10$ \\
\hline
\end{tabular}




\begin{tabular}{|c|c|c|c|}
\hline p-Coumaric acid & 1.12 & Flavonols & $37.00-147.00$ \\
\hline Ferulic acid & 0.30 & & \\
\hline \multirow[t]{8}{*}{ Cinnamic acid } & $6.00-110.00$ & Carotenoids: & \\
\hline & & $\beta$-carotene & $0.26-14.17$ \\
\hline & & $\gamma$-carotene & $0.00-1.11$ \\
\hline & & $\beta$-cryptoxanthin & $0.000-1.07$ \\
\hline & & Phytofluene & $0.00-4.70$ \\
\hline & & Phytoene & $040-5.96$ \\
\hline & & Lutein & $0.00-0.10$ \\
\hline & & Zeaxanthin & $0.00-0.03$ \\
\hline
\end{tabular}

$\mathrm{GAE}=$ Gallic acid equivalents, $\beta$-carot. $\mathrm{E}=\beta$-caroteneequivalent, $\mathrm{FW}=$ Data presented on fresh weight basis (Lecesse et al., 2007; Chauhan et al., 2001; Akin et al., 2007; Munzoruglu et al., 2003; Gurrieri et al., 2001; Dragovic-Uzelac et al., 2007; Sochor et al., 2010; Kalyoncu et al., 2009; De Rigalet al., 2000; Ruiz et al., 2008; Khachik et al., 1989).

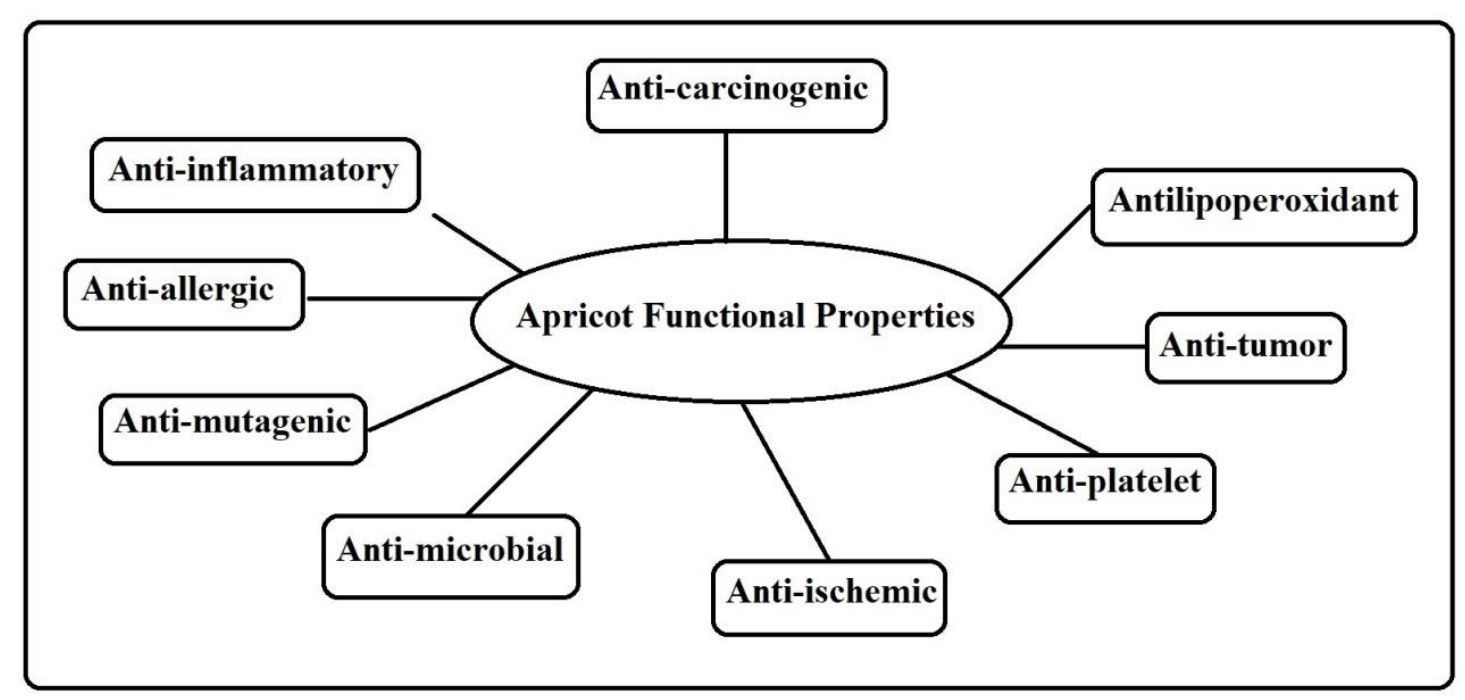

Figure 1: Functional Properties of Apricot

(De Rigal et al., 2000; Pramer and Kaushal, 1982; Lule and Xia, 2005) 


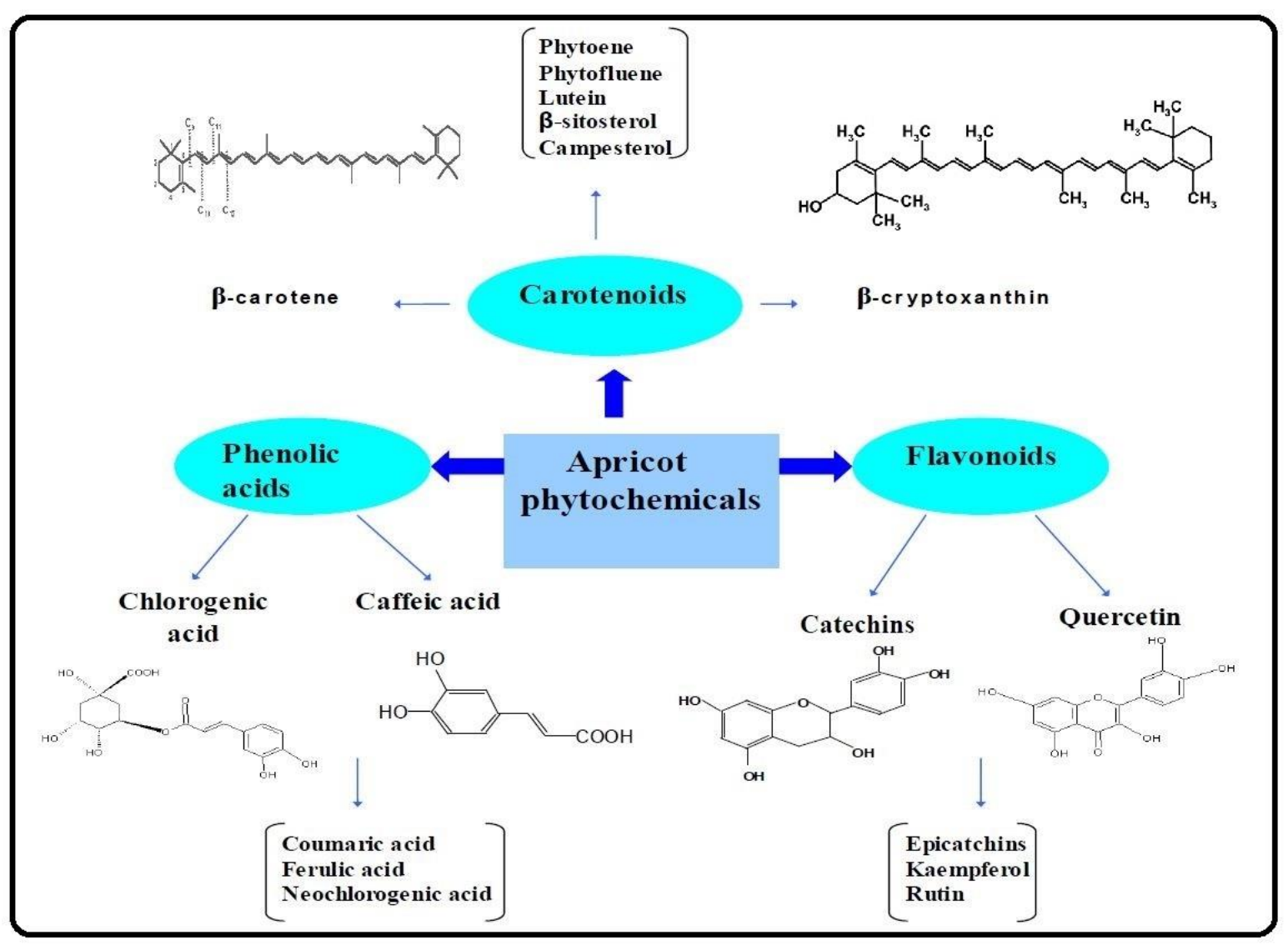

Figure 2: Important Phytochemichals of Apricot

(Akbulut and Artik, 2002; Sochor et al., 2010; Kalyoncu et al., 2009; Radi et al., 1997;

Miguel et al., 2008; Garcia-Viguera et al., 1994; Ruiz et al., 2005)

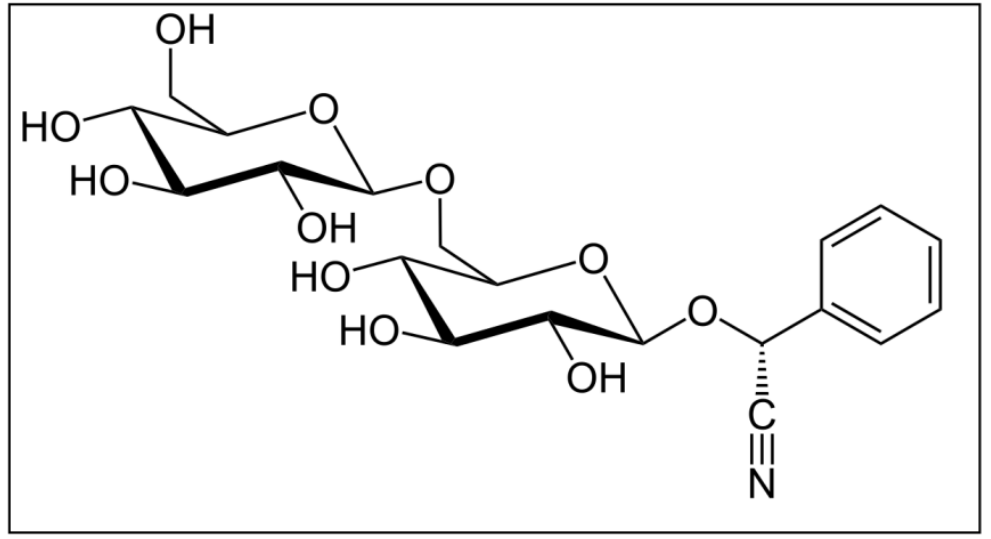

Figure 3: Amygdalin Structure 


\section{PHARMACOLOGICAL IMPORTANCE}

Many pharmacological effects of apricot and its kernel such as anti-parasitic, anti-cancer, antiaging, anti-atheroscleration, anti-anginal, cardioprotective, renoprotective, hepatoprotective and antioxidant (especially $\beta$-carotene) have been reported. It has also been reported that apricot fruit is rich in beneficial minerals, especially $\mathrm{K}, \mathrm{Fe}, \mathrm{Mg}$ and $\mathrm{P}$. Apricots are also a very good source of vitamins A, C and E, and fiber as well. Miguel and his colleagues are particularly mentioned that flavonoids have beneficial results in several cardiovascular and cerebrovascular diseases, as well as some types of cancer, Parkinson's and Alzheimer's diseases (Miguel et al., 2008). Studies have also shown that apricot has a sedative, antispasmodic, anticestodal, antimicrobial, antimutagenic, antitussive, anti-inflammatory, antinociceptive, enzyme inhibitor and tonic effects (Miyazawa et al., 2006; Yiğit et al., 2009; Yilmaz, 2010). According to Parlakpinar et al. also reported the cardioprotective activity of apricot in rats and attributed this activity to the presence of antioxidant phenolic compounds (Parlakpinar et al., 2009). Chemical components of apricot such as phenol, minerals, vitamins, lipids and carbohydrate content may vary according to altitude, apricot type, and soil structure and fertilizer use (Yilmaz, 2010). It has also been reported that vitamins A, C and E and malondialdehyde (MDA) content of apricot are better preserved in microwave drying than infrared drying (Yiğit et al., 2009). Kutlu and his colleagues reported the hepatoprotective effect exhibited by the leaf extract against paracetamol induced liver toxicity in rats, which was further confirmed in histopathological examinations (Kutlu et al., 2009). Yilmaz et al. reported that the effects of sun dried organic apricot (SDOA) supplementation to rat chow consumption on some serum mineral levels at four different rates like 1,2,5 and $10 \%$ and three different periods on both genders of rats (Yilmaz et al., 2012). According to some reports, there was an increase in serum $\mathrm{K}+$ levels in rats fed high-dose SDOA, while a decrease in $\mathrm{Ca}, \mathrm{Mg}$ and $\mathrm{P}$ levels was observed, with no difference in $\mathrm{Na}+$ and Fe levels. The chemical composition of SDOA showed that it was weaker in mineral content excluding $\mathrm{K}$ compared to rat food. The optimal supplementation was found to be $1 \%$ SDOA for 30 days. In addition, a marked difference was noticed between P levels in male rats and Fe levels in female rats (Yilmaz et al., 2012). Consumption of 1\% SDOA for 120 days of SDOA has also been reported to exert beneficial effects in rats of both sexes, particularly on red blood cells, hemoglobin and hematocrit. The reports that have mentioned above revealed that consumption of SDOA may be beneficial for the treatment, prevention and/or elimination of the risk of developing anemia in humans (Yilmaz, 2012). Considering the feeding periods, it was observed that there was an important role in the levels of albumin, alkali transferase and TP in the sexes. The $1 \%$ amount showed beneficial effects on parameters in both sexes. However, there was no significant interaction between the amounts and periods in which the diet was added (Yilmaz et al., 2013). Food supplementation with 2.5\% and 5\% 
SDOA in male rats and 10\% SDOA in female rats showed a significant positive effect on daily food intake (Yilmaz et al., 2013). In 2015, Y1lmaz et al. reported the effects of SDOA supplementation on the activity of oxidative stress enzymes such as superoxide dismutase, MDA, catalase, glutathione and glutathione $\mathrm{S}$ transferase of the large intestine in three different periods in rats, as well as beneficial effects of at least $1 \%$ SDOA consumption for 30 days in rats of either sex (Yilmaz et al., 2018). Apricot kernels appear to be an important source of natural antioxidants such as tocopherols and phenolic compounds (Durmaz et al., 2007). Ruiz et al. determined the differences between apricot varieties and their flesh color and phenolic compounds, procyanidins and anthocyanins, by HPLC. They reported that the total phenolic content varied between 32.6 and $160.0 \mathrm{mg} / 100 \mathrm{~g}$ of edible tissue, and also revealed that there was no relationship between the flesh color and phenolic content of different cultivars (Ruiz et al., 2005). On the other hand, the same authors emphasized in their report that apricot color has a great influence not only on the consumer's perception of quality, but also on their appreciation of the nutritional value of vitamin A content (Ruiz et al., 2005). Yigit et al. reported that the most effective antibacterial activity against Gram-positive bacteria was observed in methanol and water extracts of bitter grains and methanol extract of sweet apricot kernels (Yiğit et al., 2009). Also, the methanol extract of bitter kernels had very strong activity against Gramnegative bacteria. While significant antifungal activity against candida species was observed with methanol extract of bitter apricot kernels, significantly higher antioxidant activity was recorded especially in sweet kernel extracts (Karataş and Kamisli, 2007). Japanese apricot (Prunus mume) preparations inhibited Helicobacter pylori (H. pylori) colonization in the gastric mucosa, therefore, it prevents gastritis, but with unknown mechanism of inhibition as reported by Miyazawa and his friends (Miyazawa et al., 2006). In addition, the ethanol extract has significant activity against Proteus vulgaris, Escherichia coli as well as Candida albicans. The ethanol extract showed more significant antimicrobial activity compared to the aqueous extract (Jaya and Lamba, 2012). In the aforementioned study, it was reported that the effect of ethanol extract was more pronounced than the antitubercular effect exerted by aqueous and ethanol extracts of P. armeniaca (L.) fruits evaluated on Mycobactarium tuberculosis (Raj et al., 2016). In another study, it was reported that the extract showed good antimicrobial activity against Gram-positive bacteria. Therefore, it can be concluded that dried apricots are a good source of health promoting components used for therapeutic purposes (Sharma et al., 2014). 


\section{FUNCTIONAL PROPERTIES OF APRICOT}

There is an increasing demand by the consumers for foods that not only meet their basic nutritional needs but also have a preventive and therapeutic role in diseases is increasing (Muller, 1997). According to Karla (2003), "functional foods help prevent and treat diseases". The commonly used term "functional food" goes far beyond the understanding of normal nutrition and is simply defined as "any food or food component that has a positive effect on the health of the individual and alleviates or prevents a disease in addition to normal nutritional functions" (Karla, 2003). Food ingredients that meet this purpose are mostly phytochemicals that have been studied and studied for their potential role in the body. These compounds attenuate the risk of free radicals that cause oxidative damage in living cells and common degenerative disorders such as cancer and cardiovascular diseases (Boyer and Liu, 2004; Halliwell, 1999; Kaur and Kapoor, 2001; Liu, 2003). Among them, phenolic compounds are thought to be very important as antioxidants. Among its antioxidant properties; anticarcinogenic, antioxidant, anti-tumor, anti-microbial, antiplatelet, anti-ischemic, anti-allergic, anti-mutagenic and anti-inflammatory, as well as effective in alleviating cardiovascular diseases (Figure 1) (De Rigal et al., 2000; Kim et al., 2003).

\section{ANTIOXIDANT CAPACITY OF APRICOT}

Oxidative stresses cause damage to macromolecules (protein, lipids and nucleic acids) and tissue injuries due to the production of reactive oxygen species and free radicals. These conditions also lead to pathogenesis and chronic conditions, including cancer, inflammations, ulcers, diabetes and cardiovascular disease (Halliwell and Aruoma, 1991; Halliwell and Gutteridge, 1989). The antioxidant potential of apricot has been extensively investigated through different in vitro assay systems by measuring its ability to reduce free radicals and comparing it with standard reference compounds. However, in vivo studies are needed to evaluate the antioxidant potential and disease prevention role of the fruit. There are many studies have demonstrated the potential of apricot as a functional food based on its free radical scavenging activities (Leccese et al.,2007), however, differences in activity level were noted when comparing different test systems (Ruiz et al., 2005; Leccese et al., 2007; Kalyoncu et al., 2009). The differences are in genotype, maturity stage, geographic region and reference compound used as standard. Apricot has been used for centuries as a popular home remedy in China and among the mountain dwellers of the Himalayas. Folklore defines apricot as analgesic, anthelmintic, antiasthmatic, antipyretic, antiseptic, antispasmodic, sedative, emetic, emollient, expectorant, laxative, ophthalmic, pectoral, sedative, tonic, and vulnerable (Pramer and Kaushal, 1982). In Chinese medicine, apricot fruit is thought to be useful in replenishing body fluids, detoxifying and quenching thirst, while its seeds are thought to be beneficial in 
toning the respiratory system and relieving cough (Kan and Bostan, 2010). The rich nutritional composition of apricot, which contains phytonutrients, saccharides, organic acids, minerals and vitamins, is the main fact of using this fruit in folk medicine (Sochor et al., 2010; Kan and Bostan, 2010; Conev, 2003).

\section{ROLE OF APRICOT IN DEGENERATIVE DISEASES}

\section{1- Cancer}

Cancer is the most common degenerative disease today and the second cause of death in the USA after cardiovascular diseases (Borek, 2004). The immune system plays an important role in cancer incidence and inflammation, eventually causing cells to aggregate due to disturbances in pathway signaling (Noonan et al., 2007). A healthy lifestyle with a high intake of fruits and vegetables has been consistently associated with a reduced risk of several human cancers, including lung, breast, prostate and colon cancers (30-40\%). Cell death can occur by one of two different mechanisms: necrosis (accidental cell death) and apoptosis (programmed cell death). A number of pharmacological or physiological factors are responsible for the incidence of apoptosis (Noonan et al., 2007; Block et al., 1992). It is still unclear which bioactive compounds in plant foods confer protective effects against these cancers, but flavonoids have received special attention (Neuhouser, 2004). Numerous in vitro and in vivo studies have suggested that flavonoids affect important cellular mechanisms related to carcinogenesis including cell cycle control and apoptosis. There is limited data from human studies, but Neuhouser in 2004, reviewed the relationship between flavonoid intake and cancer formation and concluded that there is substantial evidence for the role of flavonoids in reducing lung cancer risk. Apricots have shown anti-carcinogenic potential in a number of studies. In 2010, Enomoto and colleagues found that consumption of 3 Japanese apricots per day had an inhibitory effect on gastric mucosal inflammation and the progression of chronic gastritis due to Helicobacter pylori infection (Enomoto et al., 2010).

\section{2- Cardiovascular Diseases}

Cardiovascular diseases are among the main causes of death worldwide. Associated risk factors include high cholesterol, high homocysteine level, atherosclerosis, and others (Schieber et al., 2001; Agarwal and Rao, 1998). Antioxidants have been found to be effective in combating coronary heart disease (CHD). Apricots provide a significant amount of fiber (soluble and insoluble) (Ishaq et al., 2009). Soluble dietary fiber is effective in lowering LDL cholesterol by binding bile acids or cholesterol during intraluminal micelle formation; thereby reducing the cholesterol content in liver cells and increasing the clearance of LDL cholesterol (Anderson $e t$ 
al., 2000; Aller et al., 2004). Parlakpınar and his colleagues conducted a study in 2009 showing the beneficial effects of apricot feeding on myocardial ischemia-reperfusion (I/R) injury in rats (Parlakpınar et al., 2009). In vivo study in animal model showed a significant effect of apricot feeding and infract sizes were found to be reduced by up to 10-20\% compared to the control group. Antioxidant capacity of rat feed was also evaluated as iron reducing power as total phenolic content, DPPH radical scavenging and in vitro antioxidant capacities were significantly increased after apricot supplementation. Results obtained by incubation of human platelets or animal cells with isolated flavonoids showed inhibition of platelet aggregation, which may be the result of suppressed cyclooxygenase activity (Ramaa et al., 2006; Howlett et al., 2008; Landolfi, 1984).

\section{3- Hemostasis}

Many epidemiological studies have shown that dietary intake of flavonoids and flavones are inversely related to the risk of cardiovascular disease (Neuhouser, 2004).

This may be due to the effect of these compounds on hemostasis, as flavonoids have been reported to inhibit platelet aggregation in vitro. Raw apricot contains $5.47 \mathrm{mg} / 100 \mathrm{~g}$ flavon-3ol (-) epicatechin, $4.79 \mathrm{mg} / 100 \mathrm{~g}$ flavon-3-ol (+) catechin and $2.08 \mathrm{mg} / 100 \mathrm{~g}$ edible flavonol fraction (USDA, 2007) and studies revealed that $2500 \mathrm{micromol} / \mathrm{L}$ flavonolquercetin and the flavone apigenin significantly inhibited collagen-induced and ADP-induced aggregation in platelet-rich plasma and inhibited platelets by almost 80-97\% (Janssen et al., 1998). Flavonoids are also known to help red blood cells fight stress caused by oxidation and help protect red blood cells against reactive oxygen species (Hodgson and Croft, 2006). For centuries, there has been a strong belief that foods and herbs have health-giving and healing properties. Today, the use of drugs to treat and alleviate diseases is increasing. However, with increased knowledge about nutrients and advanced analytical capabilities at the molecular level, researchers have had the opportunity to explore the biochemical structures, functions and relationships of numerous chemicals naturally found in foods, and their effects on the human body (Labuza, 1994). 


\section{CONTRAINDICATIONS}

Consumption of apricot kernels or Laetrile (an alternative cancer drug derived from amygdalin, marketed in Mexico and other countries outside the United States) is not recommended in pregnant or breastfeeding women due to the potential risk of birth defects (Arya et al., 2005; Ablin et al., 1979; Holzbecher et al., 1984). Thyroid disease has been observed in babies born to mothers exposed to cyanide and thiocyanate during pregnancy (Rubno and Davidoff, 1979). Apricot kernels can also lower blood pressure and therefore interact with blood pressure lowering herbs and supplements. Urticaria and rashes have also been reported.

\section{CONCLUSION}

The reviewed scientific evidence regarding the nutritional and functional properties of apricot reveals that it is a rich source of nutrients and biologically active compounds such as polyphenols, carotenoids and vitamins. These substances have important roles in preventing diseases and maintaining health. This versatile ancient herb is a reliable source of medicine, so it is used in many pharmacological activities such as anti-cancer, antioxidant, antimicrobial, as well as to treat skin infections, CNS dysfunction and genitourinary infections. The effectiveness of apricot against stomach inflammations, liver disorders, tumor formation and chronic heart diseases proves it as a functional food. However, the available information is not specific to the disease, with the exception of some studies. Therefore, there is a constant need to conduct systematic and in-depth biological studies to explore the apricots potential health benefits to come to a strong logical conclusion. The present review in this context will help researchers and entrepreneurs for the industrial use of apricot for economic benefits as a ready reference for further nutraceutical studies.

\section{REFERENCES}

[1]. Ablin RJ, Bhatti RA, Guinan PD, Knin W, Modulatory effect of oestrogen on immunological responsiveness. II. Suppression of tumor- associated immunity in patients with prostatic cancer, Clinical \& Experimental Immunology the Journal of Translational Immunology, 1979, 38, 83-91.

[2]. Agarwal, S., Rao, A.V. Tomato lycopene and low-density lipoprotein oxidation: a humandietary intervention study. Lipids, 1998, 33, 981-984.

[3]. Ahmadi, H. Fathollahzadeh, H., Mobli, H.Some physical and mechanical properties of apricot fruits, pits and kernels (C.V Tabarzeh). American-Eurasian Journal of Agriculture and Environmental Science 2008, 3(5), 703-707. 
[4]. Akbulut, M., Artik N. Kayisi ve zerdali meyvelerinin fenolic madde dagilimi ve prosesteki degisimi. Turkey 7th Food Congress.2002, 22-24 May, Ankara.

[5]. Akin, E.B., Karabulut, I., Topcu A. Some compositional properties of main Malatyaapricot (Prunus armeniaca L.) varieties. Food Chemistry, 2007, 107(2),939948.

[6]. Ali, S., Masud, T., Abbasi K.S. Physico-chemical characteristics of apricot (Prunus armeniaca L.) grown in Northern Areas of Pakistan. ScientiaHorticulture,2011, 130(2), 386-392.

[7]. Aller R, de Luis DA, Izaola O, La Calle F, del Olmo L, Fernandez L. Effect of soluble fiber intake in lipid and glucose levels in healthy subjects: a randomized clinical trial. Diabetes Research Clinical Practices. 2004; 65:7-11.

[8]. Alpaslan, M., Hayta, M. Apricot Kernel: Physical and Chemical Properties. Letters to the editor. Journal of American Oil Chemistry Society,2006, 83(5), 469-471.

[9]. Anderson, J.W., Allgood, L.D., Lawrence, A., Altringer, L.A., Jerdack, G.R., Hengehold,D.A., Morel, J.G.Cholesterol-lowering effects of psyllium intake adjunctive to diet therapy in men and women with hypercholesterolemia: meta-analysis of 8 controlled trials. American Journal of Clinical Nutrition. 2000, 71, 472-479.

[10]. Anonymous. The Illustrated Encyclopedia of Trees and Shrubs of the World.2008.Retrieved from; http://books.google.com.pk/books.html. Jan. 2012.

[11]. Arts, C.W., Van de Putte, B.,Hollman P.C.H. Catchin content of foods commonly consumed in the Netherlands. 1. Fruits vegetables, stable foods and processed foods. Journal of Agricultural and Food Chemistry,2002, 48, 1746-1751.

[12]. Arya E, Rodriguez A, Rubio J, Spada A, Libaria A, Lagunas C, Fernandez AG, Spisani S, Perez JJ, Synthesis and evaluation of diverse analogs of amygdalin as potential peptidomimetics of peptide T, Biorganic medical chemistry letters, 2005, 15, 14931496.

[13]. Bassi D, Bartotozzi F, Muzzi E, Patterns and heritability of carboxylic acid and soluble sugar in fruit of apricot (Prunus armeniaca L.), Plant breeding, 1996, 115,67-70.

[14]. Bassi, D., Bartolozzi, F., Muzzi, E. Patterns and heritability of carboxylic acids and solublesugars in fruits of apricot (Prunus armeniaca L.). Plant Breeding, 1996,115, 67 70.

[15]. Block, G., Patterson, B., Subar, A. Fruits, vegetables and cancer prevention: A review of Epidemiological evidence. Nutritional Cancer, 1992, 18, 1-30.

[16]. Borek C. Dietary antioxidants and human cancer. Integrated Cancer Therapy,2004, 3(4), 333-341.

[17]. Boyer J, Liu RH. Apple phytochemicals and their health benefits. Nutritional Journal. 2004; 3:5-19. 
[18]. Bramley, P.M. In I. Johnson and G. P. Williamson (Eds.), Phytochemical functional Foods Boca Raton: CRC. Press. 2003.

[19]. Chauhan, S.K., Tyagi, S.M., Singh, D. Pectinolytic liquefaction of apricot, plum, and mango pulps for juice extraction. International journal of Food Properties, 2001, 4(1), 103-109.

[20]. Chen JK, Chen TT. Chinese Medical Herbology and Pharmacology. California: Art of Medicine Press; 2004.

[21]. Conev, R. Apricots-Delicious Fruit and Natural Medicine. Dept. of Plant Agriculture, University of Guelph.2003,4(4), 22-24.

[22]. Crisosto, C.H., Mitcham, E.J., Kader, A.A. Apricots Postharvest Quality Maintenance Guidelines. Department of Plant Sciences.University of California, Davis, CA 95616.http://postharvest.ucdavis.edu. 1999, Accessed on 12-10-2009.

[23]. De Rigal, D., Gauillard, F., Richard-Forget, F. Changes in the carotenoid content of apricot (Prunus armeniaca, var Bergeron) during enzymatic browning: $\beta$-carotene inhibition of chlorogenic acid degradation. Journal of Science Food and Agricultural. 2000, 80,763-768.

[24]. Doymaz, I. (2004). Effect of pre-treatments using potassium metabisulphide and alkaline ethyl oleate on the drying kinetics of apricots. Biosystem Engineering, 89, 281-287.

[25]. Dragovic-Uzelac, V., Levaj, B., Mrkicm, V., Bursac, D., Boras, M. The content of polyphenols and carotenoids in three apricot cultivars depending on stage of maturity and geographical region. Food Chemistry, 2007, 102, 966-975.

[26]. Durmaz G, Alpaslan M. Antioxidant properties of roasted apricot (Prunus armeniaca L.) kernel. Food Chem 2007; 100:1177-81.

[27]. Enomoto S, Yanaoka K, Utsunomiya H, Niwa T, Inada, K. Deguchi, H. Inhibitory effects of Japanese Apricot, (Prunus mume Siebold ET Zucc.; Ume), on Helico pylorirelated chronic gastritis. European Journal of Clinical Nutrition. 2010; 64: 714-719.

[28]. Erdogan - Orhan I, Kartal M, Insight in to research on phytochemistry and biological activities of Prunus armeniaca L. (apricot), Food Research International, 44, 2010, 152.

[29]. FAO STAT. 2019. Food and Agriculture Organization of the United Nations statistical data. Web page, (http://www.fao.org), Access date: 10.02.2019.

[30]. Faust, M., Suranyi, D., Nyuito, F. Origin and Dissemination of Apricot. HorticulturalReviews. 1996, 22, 225-266.

[31]. Fermandez de Simori, B., Perez-Ilzabre, J., Haermandez, T. Importance of phenolic compounds for the characterization of fruit nectars. Journal of Agricultural Food Chemistry, 1992, 40, 1531-1535. 
[32]. Fraser, P.D., Bramley, P.M. The biosynthesis and nutritional uses of carotenoids. Progress on LipidResearch,2004, 43, 228-265.

[33]. Garcia-Viguera, C., Bridle, P., Ferreres, P., Tomas-Barberan, F.A. Influence of variety, maturity and processing on phenolic compounds of apricot nectars and jams. Z. Lebensm. UntersForsch, 1994,199, 433-436.

[34]. Gardner, P.T., White, T.A., McPhail, D.B., Duthie, G.G. The relative contributions of vitamin $\mathrm{C}$, carotenoids and phenolics to the antioxidant potential of fruit juices. Food Chemistry, 2000, 68, 471-474.

[35]. Guclu, K., Altun, M., Ozyurek, M., Karademir, S.E.,Apak, R. Antioxidant capacity of fresh, sun-dried and sulphited Malatya apricot (Prunus armeniaca L.) assayed by CUPRAC, ABTS/TEAC and folin methods. International Journal of Food Science and Technology, 2006, 41(1), 76-85.

[36]. Gurrieri, F., Audergon, J.M., Albagnac, G., Reich, M. Soluble sugars and carboxylic acids in ripe apricot fruit as parameters for distinguishing different cultivars. Euphytica, 2001,117, 183-189.

[37]. Haciseferogullari H, Gezer I, Ozcan MM, Asma BM. Postharvest chemical and physical-mechanical properties of some apricot varieties cultivated in Turkey. J Food Eng 2007; 79:364-73.

[38]. Halliwell B, Aruoma OI. DNA damage by oxygen-derived species: its mechanisms and measurement in mammalian systems. FEBS Letters. 1991; 281:9-19.

[39]. Halliwell, B. Establishing the significance and optimal intake of dietary antioxidants: the biomarker concept. Nutrition reviews.1999, 57(4), 104-113.

[40]. Halliwell, B., Gutteridge, J.M.C. Free Radicals in Biology and Medicine. Oxford, UK: Oxford University Press.1989.

[41]. Hasib, A., Jaouad, A., Mahrouz, M., Khouili, M. HPLC determination of organic acids in morocan apricots. Cienc Technol Aliment, 2002, 3(4), 207-211.

[42]. Hodgson, J.M., Croft, K.D.Dietary flavonoids: effects on endothelial function and blood pressure, Review. Journal of Science Food and Agriculture, 2006,86, 2492-2498.

[43]. Holzbecher MD, Mossma, Ellenberger HA, The cynide content of laetrile prepration apricot peach and apple seeds, Pub.med.gov, 1984, 22, 341-347.

[44]. Howlett J. Functional Foods: From Science to Health and Claims. ILSI Europe Concise Monograph Series. 2008, 19.

[45]. Huang, W., Bi, X., Zhang, X., Liao, X., Hu, X., \& Wu, J. (2013). Comparative study of enzymes, phenolics, carotenoids and color of apricot nectars treated by high hydrostatic pressure and high temperature short time. Innovative Food Science and Emerging Technology, 18, 74-82. 
[46]. Igual, M., García-Martínez, E., Martín-Esparza, M.\& Martínez

Navarrete, N. (2012). Effect of processing on the drying kinetics and functional value of dried apricot. Food Research International, 47, 284-290.

[47]. Ishaq S, Rathore HA, Majeed S, Awan S, Shah SZA. Studies on the physico-chemical and organoleptic characteristics of apricot (Prunus armeniaca L.) produced in Rawalakot, Azad Jammu and Kashmir during storage. Pakistan Journal of Nutrition. 2009; 8(6):856-860.

[48]. Janssen, K., Mensink, R.P., Cox, F.J.J., Harryvan, J.L., Hovenier, R., Hollman, P.C.H., Katan, M.B. Effects of the flavonoids quercetin and apigenin on hemostasis in healthy volunteers: results from an in vitro and a dietary supplement study. American Journal of Clinical Nutrition, 1998, 67, 255-62.

[49]. Jaya S, Lamba HS. Antimicrobial activity of fruits of Prunus armeniaca (L.). J Drug Deliv Ther 2012; 4:163-6.

[50]. Kalyoncu, I.H., Akbulut M., Coklar, H. Antioxidant capacity, total phenolics and some chemical properties of semi-mature apricot cultivars grown in Malatya, Turkey. World Applied Science, 2009,6(4), 519-523.

[51]. Kan T and Bostan SZ. Changes of Contents of Polyphenols and Vitamin a of Organic and Conventional Fresh and Dried Apricot Cultivars (Prunus armeniaca L.). World Journal of Agricultural science, 2010, 6 (2), 120-126.

[52]. Karataş F, Kamisli F. Variations of vitamins (A, C and E) and MDA in apricots dried in IR and microwave. J Food Process Eng. 2007; 78:662-8.

[53]. Karla EK. Nutraceutical-Definition and Introduction. AAPS, Pharmaceutical Science. 2003; 5(3):1-2.

[54]. Kaur, C., Kapoor, H.C. Antioxidants in fruits and vegetables-the millenniums health. International Journal of Food Science and Technology,2001,36, 703-725.

[55]. Kim, D.O., Jeong, W., Lee, S.C.Y. Antioxidant capacity of phenolic phytochemicals from various cultivars of plums. Food Chemistry, 2003, 81, 321-326.

[56]. Kutlu T, Durmaz G, Ates B, Erdogan A. Protective effect of dietary apricot kernel oil supplementation on cholesterol level and antioxidant status of liver in hypercholesteremic rats. J Food Agric Environ 2009; 3(4):61-5.

[57]. Labuza, T. Foreword, in Functional Foods; Designer Foods, Pharma foods, Nutraceuticals (ed I. Goldberg). Chapman and Hall, London, 1994,pp. xi-xiii.

[58]. Lairon, D. Les fibres alimentaires. La Recherche, 1990, 21, 284-92.

[59]. Landolfi, R., Mower, R.L., Steiner,M. Modification of platelet function and arachidonic acid metabolism by bioflavonoids: structure-activity relations. Biochemical Pharmacology, 1984, 33, 1525-1530. 
[60]. Leccese, A., Bartolini, S., Viti, R. Total antioxidant capacity and phenolics content in apricot fruits. International Journal of Fruit Science,2007, 7(2), 3-16.

[61]. Leccese, A., Viti, R., Bartolini, S. The effect of solvent extraction on antioxidant properties of apricot fruit. CentralEuropean Journal ofBiology, 2011,6 (2), 199-204.

[62]. Lee, S.K., Kader, A.A. Pre-harvest and post-harvest factors influencing vitamin C content of horticultural crops. Postharvest Biology and Technology,2000, 20, 207-220.

[63]. Lichou, J., Jay, M., Vaysse, P., Lespinasse, N. Reconnaitre les variétésd, apricots. Editions Ctifl, France, 2003, p. 17-29.

[64]. Liu, R.H. Health benefits of fruit and vegetables are from additive and synergistic combinations of phytochemicals. American Journal of Clinical Nutrition,2003, 78, 517-520.

[65]. Mandal S, Suneja P, Malik SK, Mishra SK, Variability in kernel oil, its fatty acid and protein contents of different apricot (Prunus armeniaca) genotype, Indian Journal of Agricultural science, 2007, 77, 464-466.

[66]. Marty I, Bureau S, Sarkissian G, Gouble B, Audergon JM, Albagnac G. 2005. Ethylene regulation of carotenoid accumulation and carotenogenic gene expression in colourcontrasted apricot varieties (Prunus armeniaca L). Journal of Experimental Botany, 1990, 56, 1877-1886.

[67]. Mazza, G., Miniati, E. Anthocyanins in fruits, vegetables and grains. Boca Raton, FL: CRC Press, 1993, p.362.

[68]. Miguel, G., Dandlen, S., Neves, A, Antunes, D. Flavonoids content of different apricot (Prunus armeniaca L.) cultivars. 4th IASME/WSEAS International Conference on Energy, Environment, Ecosystems and Sustainable Development (EEESD'08). Algarve, Portugal, June 11-13, 2008.

[69]. Milazzo S, Horneber M, Ernst E. Laetrile treatment for cancer. Cochrane Database of Systematic Reviews 2015, Issue 4. Art. No.: CD005476.

[70]. Minaiyan M, Ghannadi A, Asadi M, Etemad M, Mahzouni P. Anti-inflammatory effect of Prunus armeniaca L. (Apricot) extracts ameliorates TNBS-induced ulcerative colitis in rats. Res Pharm Sci 2014;4:225-31.

[71]. Miyazawa M, Utsunomiya H, Inada K, Yamada T, Okuno Y, Tanaka H, et al. Inhibition of Helicobacter pylori motility by (+)-syringaresinol from unripe Japanese apricot. Biol Pharm Bull 2006;29(1):172-3.

[72]. Monsen, E.R. Nutritional bioavailability of iron. American Chemical Society, 1982, pp. 85-95.

[73]. Muller, H. Die taglicheaufnahme von Carotinoiden (carotine und xanthophylle) ausgesamtnahrungsprobe und die carotinoidgehalteausgewahlterGemu se und Obstarten. Z Ernahrungswiss, 1996, 35, 45-50. 
[74]. Muller. H. Determination of the carotenoid content in selected vegetables and fruit by HPLC and photodiode array detection. Z LebensUntersForsch,1997, 204, 88-94.

[75]. Munzuroglu, O., Karatas, F., Geckil, H. The vitamin and selenium contents of apricot fruit of different varieties cultivated in different geographical regions. Food Chemistry, 2003, 83, 205-212.

[76]. Neuhouser ML. Dietary flavonoids and cancer risk: evidence from human population studies. Nutrition and Cancer, 2004; 50:1-7.

[77]. Noonan, D.M., Benelli, R., Albini, A. Angiogenesis and cancer prevention. A vision. Recent results. Cancer Research, 2007, 174, 219-224.

[78]. Orhan, I., Koca, U., Aslan, S., Kartal, M., Kusmenoglu, S. Fatty acid analysis of some Turkish apricot seed oils by GC and GC-MS techniques. Turkish Journal Pharmaceutical Science, 2008, 5(1), 29-34.

[79]. Parlakpinar, H., Olmez, E., Acet, A., Ozturk, F., Tasdemir, S., Ates, B., Gul, M., Otlu, A. Beneficial effects of apricot-feeding on myocardial ischemia-reperfusion injury in rats. Food Chemistry and Toxicology, 2009, 47, 802-808.

[80]. Pramer, C., Kaushal, M.K. Wild fruits of Sub- Himalayan Region.Kalyani Publishers, New Delhi, India.1982.

[81]. Prasad D, Joshi RK, Pant G, Rawat MSH, Inoue K, Shingu T, An type proanthocynidine from Prunus armeniaca, Journal of natural product, 1998, 61, 11231125.

[82]. Pszczola, D.E. "Fiber has a strong supporting role in nutraceutical movement". Food Technology, 1998, 52, 90-96.

[83]. Radi, M., Mahrouz, M., Jaouad, A., Tacchini, M., Aubet, S., Hugues, M., Amiot, M.J. Phenolic composition, browning susceptibility, and carotenoid content of several apricot cultivars at maturity. Horticultural Science, 1997, 32, 1087-1091.

[84]. Raj V, Jain A, Chaudhary J. Prunus armeniaca (Apricot): An Overview. J Pharm Res 2012; 8:3964-6.

[85]. Raj V, Mishra AK, Mishra A, Ali NK. Hepatoprotective effect of Prunus armeniaca L. (Apricot) leaf extracts on Paracetamol induced liver damage in Wistar rats. Pharm J 2016; 2:154-8.

[86]. Ramaa, C.S., Shirode, A.R., Mundad, A.S., Y kadam, V.J. Nutraceuticals an emerging era in the treatment and prevention of cardiovascular diseases. Current Pharmaceuticals and Biotechnology, 2006, 7 (1), 15-23.

[87]. Rao AV, Rao LG. Carotenoids and human health. Pharmacological Research, 2007, 55, 207-216.

[88]. Rice-Evans, C.A., Miller, N.J., Paganga, G. Antioxidant properties of phenolic compounds. Trends in Plant Science, 1997, 2, 152-159. 
[89]. Riu-Aumatell, M., Lopez-Tamames, E., Buxadera, S. Assessment of the volatile composition of juices of apricot, peach, and pear according to two pectolytic treatments. Journal of Agricultural and Food Chemistry, 2005, 53, 7837-43.

[90]. Rubno MJ, Davidoff F, Cynide poisoning from Apricot seeds. The journal of the American Medical Association, 1979, 241, 359.

[91]. Ruiz D, Egea J, Thomas - BFA, Gil MI, Carotenoids from new apricot (Prunus armeniaca L.) varieties and their relationship with flesh skin color, Journal of Agricultural and Food chemistry, 2005, 53, 6368-6374.

[92]. Ruiz, D., Reich, M., Bureau, S., Renard, C.M.G.C., Audergon, J. Application of reflectance colorimeter measurements and infrared spectroscopy methods to rapid and nondestructive evaluation of carotenoids content in apricot (Prunus armeniaca L.). Journal of Agricultural and Food Chemistry, 2008, 56, 4916-4922.

[93]. Sahin S, Cynide poisoning in children caused by Apricot seeds, Health \& medical Informatics, 2011, 2, 1-2.

[94]. Sass-Kiss, A., Kiss, J., Milotay, P., Kerek, M.M., Toth-Markus, M. Differences in anthocyanin and carotenoid content of fruits and vegetables. Food Research International 2005, 38, 1023-1029.

[95]. Schieber A, Stintzing FC, Carle R. By-products of plant food processing as source of functional compounds-recent developments. Trends in Food Science and Technology. 2001; 12:401-13.

[96]. Sharma S, Satpathy G, Gupta RK. Nutritional, phytochemical, antioxidant and antimicrobial activity of Prunus armenicus. J Pharmacogn Phytochem 2014; 3:23-8.

[97]. Socher J, Pavlik D, Babula P, Krska B, Horna A, AdamV, Provaznik I, Kizer R, Content of phenolic compound \& antioxidant capacity in fruit of Apricot Genotype, Molecules, 2010, 15, 6285-6305.

[98]. Tamura, M., Ohnishi, Y., Kotani, T., Gato, N. Effects of new dietary fiber from Japanese apricot (Prunus mume Sieb. Et Zucc.) On gut function and intestinal microflorain adult mice. International Journal of Molecular Science, 2011, 12, 20882099.

[99]. Turans S, Topcu A, Karabulut I, Vural H, Hayaloglu AA, Fatty acid triacylglycerol phytosterol and tocopherol variation in kernel oil of Malatya apricot from turkey, Journal of Agricultural and food chemistry, 2007, 55, 10787-10794.

[100]. USDA. United States Department of Agriculture, National Nutrient Database; Nutrition facts and information for apricots, raw. Retrieved from; http://www.nutritiondata.com. 2005. Accessed on 2-11-2012. 
[101]. USDA. United States Department of Agriculture. Database for Flavonoid Content of Selected Foods. www.nal.usda.gov/fnic/foodcomp/Data/Flav/Flav02-1.pdf. 2007. Accessed on 13-5-12.

[102]. Vinson, J.A., Hao, Y., Su, X., Zubik, L. Phenol antioxidant quantity and quality in foods: Vegetables. Journal of Agricultural and Food Chemistry, 1998, 46 (9), 36303634 .

[103]. Yiğit D, Yiğit N, Mavi A. Antioxidant and antimicrobial activities of bitter and sweet apricot (Prunus armeniaca L.) kernels. Braz J Med Biol Res 2009; 42 (4):346-52.

[104]. Yiğit D, Yiğit N, Mavi A. Antioxidant and antimicrobial activities of bitter and sweet apricot (Prunus armeniaca L.) kernels. Braz J Med Biol Res 2009; 42(4):346-52.

[105]. Yilmaz I, Dogan Z, Soysal H. The effects of dried apricot supplementation on daily food intake in rats. Turk J Pharma Sci 2013; 1:137-44.

[106]. Yilmaz I, Hatipoglu HS, Taslidere E, Karaaslan M. Comparing the regenerative effects of Silymarin and Apricot on liver regeneration after partial hepatectomy in rats. Biomed Res 2018;29 (7):1465-73.

[107]. Yilmaz I, Temel I, Gursoy S, Dogan Z, Turkoz Y. Effects of sun dried organic apricot on some serum mineral levels in rats. Int Res J Pharm 2012; 03:62-7.

[108]. Y1lmaz I, Temel I, Gursoy S, Dogan Z. The effects of apricot on serum proteins and liver enzymes in rats. J Food Nutr Res 2013; 2:101-06.

[109]. Yilmaz I. Carotenoids. J Turgut Ozal Med Cent 2010;17:223-31. 6. Erdogan-Orhan I, Kartal M. Insights into research on phytochemistry and biological activities of Prunus armeniaca L. (apricot). Food Res Int 2011; 44:1238-343.

[110]. Yilmaz I. Effects of sun dried organic apricot on some hematological parameters in rats. J Pharm Res 2012; 3:18-22. 